DOI: doi.org/10.21009/IJLECR.062.20

Received: 12 May 2020

Revised: 11 June 2020

Accepted: 5 November 2020

Published: 1 December 2020

\title{
THE APPLICATION OF MOBILE ASSISTED LANGUAGE LEARNING (MALL) IN TEACHING PRONUNCIATION
}

\author{
Ila Amalia ${ }^{1, a)}$ \\ UIN Sultan Maulana Hasanuddin, Banten, Indonesia ${ }^{1)}$ \\ ila.amalia@uinbanten.ac.id ${ }^{\text {a) }}$
}

\begin{abstract}
Mobile learning is experiencing a drastic change. Whereas the initial period of mobile learning tends to propose carefully skilled activities by teachers and technology, students are gradually motivated by their personal learning needs, including those that arise from greater mobility and traveling activities. Through the process, mobile learning use, particularly the Mobile-Assisted Language Learning (MALL), has become an essential tool in the teaching and learning process. This research investigates the use of Mobile Assisted Language Learning (MALL) in teaching pronunciation at a secondary school. Using experimental study, the research aims to know the effectiveness of MALL in teaching pronunciation in the experimental group, compared to another group with non-MALL. The result shows that students in the experimental group performed better in pronunciation skills compared to their peers. Thus the use of MALL in teaching pronunciation was also effective in improving students' pronunciation skills with the t-count (5.97), which is higher than the t-table (2.00 and 2.67).
\end{abstract}

Keywords: Mobile Assisted Language Learning (MALL), Pronunciation, Secondary school, Experimental study, Method

Pronunciation is a critical aspect of verbal communication. Pronunciation is a feature of speech and spelling (Hewings, 2009). Cook (1996), as cited in Pourhosein Gilakjani (2016), defined pronunciation as the production of English sounds. Pronunciation is learned by repeating sounds and correcting them when produced inaccurately. When learners start learning pronunciation, they make new habits and overcome the difficulties resulting from the first language.

Meanwhile, Richard and Schmidt (2002) defined pronunciation as the method of producing particular sounds. From the definitions, pronunciation concerns mainly with spoken language. It means pronunciation is vital for both speaking and listening. Since pronunciation related to the process of communication, intelligibility becomes the primary concern in pronunciation teaching.

People can understand what a speaker says if his or her pronunciation is proper. Pronunciation is essential for both speaking and listening skills (Marks, 2007). Competence in pronunciation is related to speaking, listening and reading. Insufficient pronunciation might have an adverse effect on those skills. For instance, when people do not recognize the essential sounds or words from a speaker in the listening section, they will not comprehend the meaning of those words.

In the teaching-learning process, the reality is far from ideal. There are still many obstacles found in pronunciation practices by students who learn English as a foreign language. The fact showed that most of the students felt difficult in pronouncing the word or sentence of English text and difficult to understand what their teacher said. The problem the students face in pronunciation 
practices could be from another two aspects; from the teacher aspect and the students' aspect.

From the students' aspect, it was found that learning English was difficult because the characteristics the English is different from the students' first language. Mostly the students found difficulties in pronouncing English words accurately. In the learning activities, most of the students felt anxious, afraid, and felt not confident when they have to speak in English. Besides, the students were lazy and lack of motivation to practice pronunciation skills.

From the teacher's perspective, it was found that most English teachers still use the traditional or conventional method in teaching pronunciation. That was the teaching-learning process still focused on the teacher, not on the students. The students did not have much opportunity to practice their skills. The students were hardly understood what the teacher said due to a lack of comprehension of pronunciation.

One of the ways to make the teaching pronunciation effective is by making the students active so they will enjoy learning, and at the same time, the students can improve their pronunciation skills. Speaking can be a fun activity when the students feel confident in pronouncing the words or sentences, and the teacher knows the strategy or technique in teaching pronunciation.

There are some alternative strategies in teaching pronunciation that can improve students' pronunciation skills and comprehension, such as by using games, sings, short conversations, or using digital media. In this research, the writer explores using Mobile Assisted Language Learning (MALL) in teaching pronunciation as an alternative teaching strategy, digital-based media.

Since mobile-assisted language learning (MALL) was first coined by Chinnery (2006), mobile devices' use to support language learning has increased fruitfully. MALL has been considered as a part of both mobile learning and computer-assisted language learning that enable the students' new ways of learning, emphasizing continuity or spontaneity of access and interaction across different contexts of use (Kukulska-Hulme and Shield, 2008).

In the $21^{\text {st }}$ century era, educational methods and instructions have been changing at a pace commensurate with the rapid technological advances in other phases of a global society. MobileAssisted Language Learning (MALL) is one of the teaching media that can be used in teaching pronunciation. It entails language teaching methodology which can effectively integrate listening, reading, and speaking activities. It can also develop academic study, critical thinking, and research skills (Gholami and Azami, 2012).

Numerous studies have reported on the use of mobile devices being used to develop language skills in the last few decades. Al Khayat (2019) explores using MALL in teaching English to enhance students' behaviors. Moreover, it can increase students' learning behaviors. Moreover, it can also enhance students' speaking confidence and support their ability to listen in a foreign language. Saran et al (2009) point out that using mobile phones in educational settings may help learners be more motivated and might make it possible to overcome the difficulties teachers or parents experience to make learners start studying.

Kim, Heyoung \& Kwon, Yeonhee (2012) have the same voice about the mobile application in teaching English. Their study reveals that mobile applications seem useful in providing a personal and learner-centered learning opportunity with ubiquitously accessible and flexible practices. Hadi \& Emzir (2016) conducted three-cycle action research to investigate the effect of using MALL on students' speaking ability. The study shows that Mobil Assisted Language Learning (MALL) significantly helped the students improve their ability to speak English. It was indicated by the improvement of the scores in each cycle, from 53,20 in the first cycle, 61,20 in the second cycle, and 80,00 in the third cycle.

Another study related to the use of digital or computer applications in teaching instruction was conducted by Harunasari \& Rahmat (2015). Under the term CALL (Computer Assisted Language Learning), this study was conducted to examine the effectiveness of Moodle and 
Content Management System, namely (CMS) Lokomedia as CALL-Based instructions in teaching speaking for English university students. It was revealed that the development of the models could improve the students' speaking skills. The improvement could be seen from the increase of the mean scores before the implementation of the model $(61,00)$ and after the implementation of the model $(69,00)$. The two models are effective in improving the students' speaking skills.

From several studies that have been explained above, there is still space for doing explorative study concerning the use of the mobile application in teaching English. Since the use of the digitalbased application is developing immeasurable in this 21st-century industrial revolution era, this study is still relevant to be conducted. This research will focus on using Mobile Assisted Language Learning (MALL) in teaching pronunciation, especially on the level of segmental aspect, at the secondary school.

\section{METHOD}

A research approach involving quantitative components was employed in this study. The quantitative part of the study consisted of a pre-test/post-test quasi-experimental design. The treatment was carried out for three weeks. The participants of this study were 52 eighth grade students of MTs Nurul Falah Serang secondary school. The distribution of the participants of the study is presented in the following table.

TABLE 1. The Distribution of the Participants

\begin{tabular}{|c|c|}
\hline Group & Participants \\
\hline Control & 26 students \\
\hline Experiment & 26 students \\
\hline Total & 52 students \\
\hline
\end{tabular}

The instruments of the study consisted of three parts: (1) pre-test, (2) instructional Material (MALL): Pronunciation Application By Kepham from Android, and (3) Post-test. The pre and post-test were given to both the control group and the experiment group before and after the instruction of using MALL was delivered. In the pre and post-test, the students from both groups were required to pronounce ten English words according to their competence. This was done to measure the students' pronunciation skills.

The researcher recorded the students' pronunciations by using a digital voice recorder and employed the Educational Testing Service (1985) rubric to measure the students' pronunciation. The rubric had undergone some modifications and adjustments to meet the purpose of the study. The testing rubric is presented as follows.

TABLE 2. Pronunciation Test Rubric

\begin{tabular}{|c|l|}
\hline Scales & \multicolumn{1}{|c|}{ Descriptions } \\
\hline 0 & $\begin{array}{l}\text { Frequent phonemic errors and foreign stress and } \\
\text { intonation patterns that cause the speaker to be } \\
\text { unintelligible }\end{array}$ \\
\hline 3 & $\begin{array}{l}\text { Frequent phonemic errors and foreign stress and } \\
\text { intonation patterns that cause the speaker to be } \\
\text { occasionally unintelligible }\end{array}$ \\
\hline 4 & $\begin{array}{l}\text { Some phonemic errors and foreign stress and } \\
\text { intonation patterns, but the speaker is intelligible }\end{array}$ \\
\hline 5 & $\begin{array}{l}\text { Occasional non-native pronunciation errors, but the } \\
\text { speaker is intelligible. }\end{array}$ \\
\hline
\end{tabular}


The experiment phase consisted of three weeks. Two different study modes were employed to explore the comparative effectiveness of pronunciation materials delivered through these two modes. A mobile-based application for teaching pronunciation (Pronunciation application By Kepham from Android) was given to the experiment group, and a traditional teaching method (audio-lingual method with the teacher as the model) was given to the control group.

The descriptive statistical analysis was used to find out the differences in the students' scores between the experiment and the control group. In analyzing the effectiveness of using the media, the inferential statistical analysis was used. The t-test was used with a significant degree of $5 \%$ and $1 \%$ (Sudjiono, 2019).

$$
t_{\mathrm{o}}=\frac{M_{1-M_{2}}}{\sqrt{\left(\frac{\sum x_{1}^{2}+\Sigma x_{2}{ }^{2}}{N_{1}+N_{2}-2}\right)\left(\frac{N_{1}+N_{2}}{N_{1} \cdot N_{2}}\right)}}
$$

$M_{1} \quad=$ Mean score of the experiment class

$M_{2}=$ Mean score of the control class

$\sum x_{1}^{2}=$ Sum of square deviation score in experiment class

$\sum x_{2}^{2}=$ Sum of square deviation score in the control class

$N_{1} \quad=$ Number of students of experiment class

$N_{2}=$ Number of students of the control class

$2=$ Constant Number

df $=$ Degree of Freedom $\left(\mathrm{df}=N_{1}+N_{2}-2\right)$

\section{RESULTS AND DISCUSSIONS}

The purpose of the study is to determine the effectiveness of using Mobile Assisted Language Learning (MALL) in teaching pronunciation and to know whether there is significant scores' difference between students who received treatment with MALL with their peers who did not receive treatment with MALL. To gather the information, the writer analyzed the result from the students' scores in pre-test and post-test (both experiment and control class) to know the effect of Mobile Assisted Language Learning (MALL) in improving students' pronunciation skills. The description of the students' scores is presented in the following tables:

TABLE 3. The Score of Pre-Test and Post Test in Experiment Group

\begin{tabular}{|c|c|c|c|}
\hline No & Name & Pre-Test & Post-Test \\
\hline 1 & AR & 74 & 82 \\
\hline 2 & AR & 57 & 78 \\
\hline 3 & A & 62 & 74 \\
\hline 4 & AN & 70 & 80 \\
\hline 5 & BN & 82 & 90 \\
\hline 6 & DK & 64 & 78 \\
\hline 7 & DS & 67 & 80 \\
\hline 8 & DAT & 72 & 81 \\
\hline 9 & FM & 64 & 77 \\
\hline 10 & FS & 67 & 75 \\
\hline 11 & IN & 64 & 80 \\
\hline 12 & II & 63 & 82 \\
\hline 13 & K & 85 & 92 \\
\hline 14 & KH & 68 & 79 \\
\hline
\end{tabular}




\begin{tabular}{|c|c|c|c|}
\hline 15 & MNI & 71 & 88 \\
\hline 16 & MA & 70 & 80 \\
\hline 17 & MH & 62 & 83 \\
\hline 18 & MR & 67 & 78 \\
\hline 19 & MS & 80 & 67 \\
\hline 20 & RP & 73 & 85 \\
\hline 21 & RAM & 85 & 97 \\
\hline 22 & RM & 57 & 76 \\
\hline 23 & RM & 54 & 68 \\
\hline 24 & SS & 66 & 77 \\
\hline 25 & SH & 55 & 60 \\
\hline 26 & UF & 65 & 68 \\
\hline & $\sum$ & 1764 & 2055 \\
\hline & X & 67.85 & 79.04 \\
\hline
\end{tabular}

From the table above, it can be seen that the average scores from pre-test to post-test in the experiment group is increased from 67,85 to 79,04 . It is indicated that the application of MALL in teaching pronunciation has a significant effect on students' learning behavior, which then, in turn, can influence the students' performances.

TABLE 4. The Score of Pre-Test and Post Test in Control Group

\begin{tabular}{|c|c|c|c|}
\hline No & Name & Pre-Test & Post-Test \\
\hline 1 & AB & 54 & 66 \\
\hline 2 & AMR & 63 & 76 \\
\hline 3 & A & 45 & 57 \\
\hline 4 & A & 62 & 65 \\
\hline 5 & AP & 51 & 64 \\
\hline 6 & AM & 70 & 64 \\
\hline 7 & AA & 63 & 74 \\
\hline 8 & AI & 72 & 75 \\
\hline 9 & DA & 62 & 72 \\
\hline 10 & E & 60 & 55 \\
\hline 11 & FI & 75 & 73 \\
\hline 12 & HR & 60 & 66 \\
\hline 13 & IF & 66 & 57 \\
\hline 14 & IM & 56 & 66 \\
\hline 15 & LN & 54 & 60 \\
\hline 16 & MMT & 53 & 61 \\
\hline 17 & MR & 65 & 68 \\
\hline 18 & MF & 75 & 82 \\
\hline 19 & M & 73 & 77 \\
\hline 20 & NF & 62 & 57 \\
\hline 21 & PS & 55 & 50 \\
\hline 22 & RAM & 57 & 60 \\
\hline 23 & SU & 66 & 70 \\
\hline 24 & SK & 72 & 67 \\
\hline 25 & SS & 57 & 63 \\
\hline
\end{tabular}




\begin{tabular}{|c|c|c|c|}
\hline 26 & $\mathrm{~S}$ & 55 & 45 \\
\hline & $\sum$ & 1603 & 1690 \\
\hline & $\mathrm{X}$ & 61.65 & 65,00 \\
\hline
\end{tabular}

The result from the control group that is represented by the above table also has a significant change. The average score had increased from 61,65 in the pre-test to 65,00 in the post-test, even though the control group had undergone the teaching instruction with the conventional method (non-MALL method). The summary of the result is described in the following graphics.
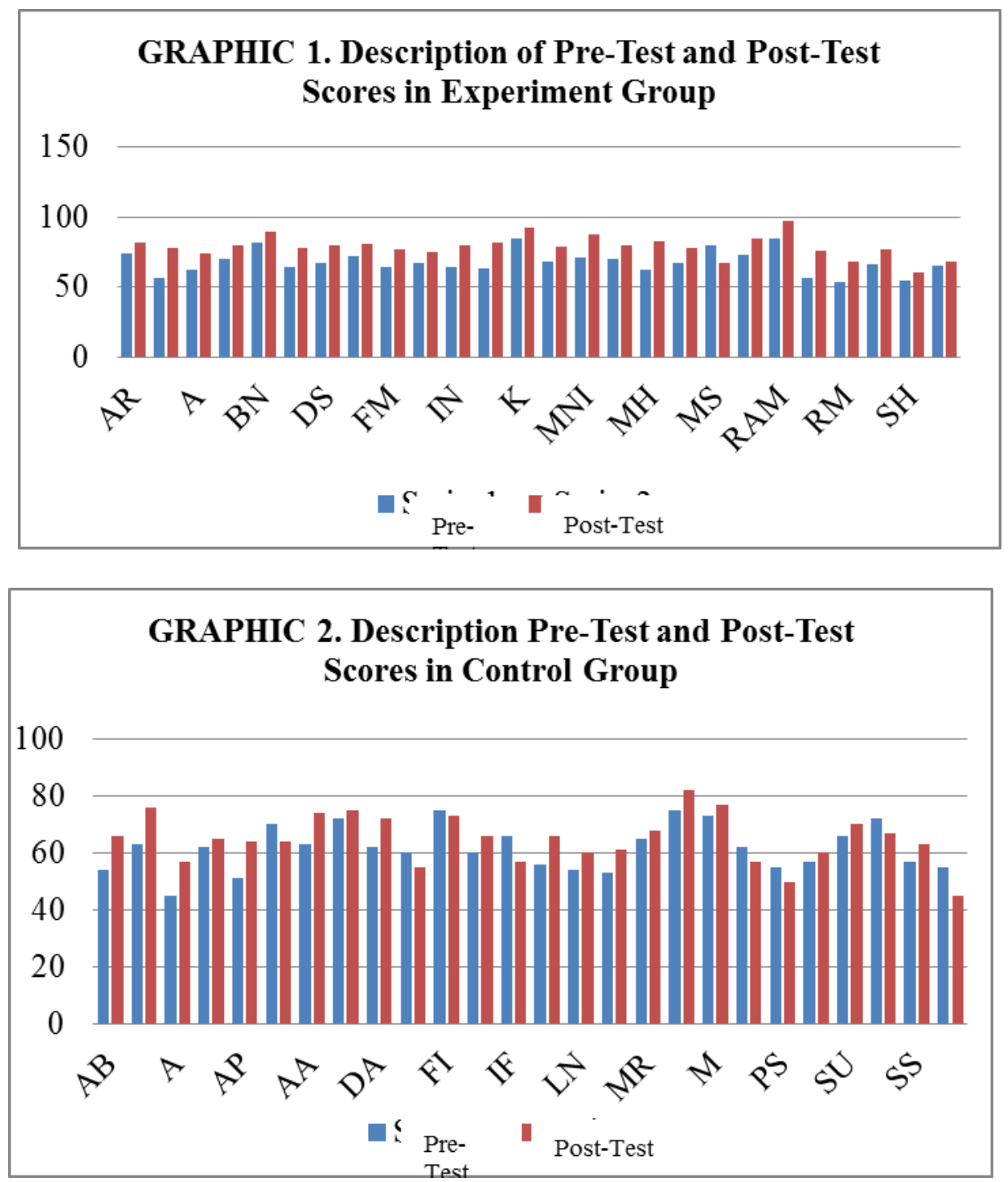

In general, the scores of the post-test in the experiment class ware better than the scores of the post-test in the control class. It can be seen from the total amount of the scores of the post-test in the experiment class was 2055, and the pre-test was 1764 , and the average score of the post-test was 79.04 and pre-test was 67.85. Meanwhile, the total amount of the post-test scores in the control class was 1690, and the pre-test was 1603, and the average score of the post-test was 65,00, and the pre-test was 61.65. These results showed that students who received instruction with MALL application had better scores and performances than the students who did not.

The use of teaching strategy with mobile applications had a significant effect on students' 
behavior. The students felt challenging and were motivated to learn due to the interactive teaching activities in the classroom. The use of mobile applications allowed the students to explore their language experience that could arouse their self-confidence. In the end, it had a positive effect on their comprehension and performance.

After describing the data, the researcher analyzed the scores by using inferential statistic analysis to answer the research purposes and to prove the research hypothesis. The result of the data analysis can be seen in the following section.

TABLE 5. The Score of Frequency Distribution

\begin{tabular}{|c|c|c|c|c|c|c|}
\hline No & $\mathbf{x 1}$ & $\mathbf{x 2}$ & $\mathbf{X 1}$ & $\mathbf{X 2}$ & $\mathbf{X 1}^{\mathbf{2}}$ & $\mathbf{X 2}^{\mathbf{2}}$ \\
\hline 1. & 82 & 66 & 2.96 & 1 & 8.76 & 1 \\
\hline 2. & 78 & 76 & -1.04 & 11 & 1.08 & 121 \\
\hline 3. & 74 & 57 & -5.04 & -8 & 25.40 & 64 \\
\hline 4. & 80 & 65 & 0.96 & 0 & 0.92 & 0 \\
\hline 5. & 90 & 64 & 10.96 & -1 & 120.12 & 1 \\
\hline 6. & 78 & 64 & -1.04 & -1 & 1.08 & 1 \\
\hline 7. & 80 & 74 & 0.96 & 9 & 0.92 & 61 \\
\hline 8. & 81 & 75 & 1.96 & 10 & 3.84 & 100 \\
\hline 9. & 77 & 72 & -2.04 & 7 & 4.16 & 49 \\
\hline 10. & 75 & 55 & -4.04 & -10 & 16.32 & 100 \\
\hline 11. & 80 & 73 & 0.96 & 8 & 0.92 & 64 \\
\hline 12. & 82 & 66 & 2.96 & 1 & 8.76 & 1 \\
\hline 13. & 92 & 57 & 12.96 & -8 & 167.96 & 64 \\
\hline 14. & 79 & 66 & -0.04 & 1 & 0.0016 & 1 \\
\hline 15. & 88 & 60 & 8.96 & -5 & 80.28 & 25 \\
\hline 16. & 80 & 61 & 0.96 & -4 & 0.92 & 16 \\
\hline 17. & 83 & 68 & 3.96 & 3 & 15.68 & 9 \\
\hline 18. & 78 & 82 & -1.04 & 17 & 1.08 & 289 \\
\hline 19. & 67 & 77 & -12.04 & 12 & 144.96 & 144 \\
\hline 20. & 85 & 57 & 5.96 & -8 & 35.52 & 64 \\
\hline 21. & 97 & 50 & 17.96 & -15 & 322.56 & 225 \\
\hline 22. & 76 & 60 & -3.04 & -5 & 9.24 & 25 \\
\hline 23. & 68 & 70 & -11.04 & 5 & 121.88 & 25 \\
\hline 24. & 77 & 67 & -2.04 & 2 & 4.16 & 4 \\
\hline 25. & 60 & 63 & -19.04 & -2 & 362.52 & 4 \\
\hline 26 & 68 & 45 & -11.04 & -20 & 121.88 & 400 \\
\hline$\sum$ & $\mathbf{2 0 5 5}$ & $\mathbf{1 6 9 0}$ & $\mathbf{0 . 0 4}$ & $\mathbf{0}$ & $\mathbf{1 5 8 0 . 9 2}$ & $\mathbf{1 8 5 8}$ \\
\hline & & & & & & \\
\hline
\end{tabular}

Note :

$\mathrm{x} 1=$ Score Post-Test (Experiment Class)

$\mathrm{X} 1=\mathrm{x} 1-\mathrm{M} 1$

$\mathrm{x} 2=$ Score Post-Test (Control Class)

$\mathrm{X} 2=\mathrm{x} 2-\mathrm{M} 2$

$\mathrm{X} 1{ }^{1}=$ Squared value of $\mathrm{X} 1$

$\mathrm{X} 2^{2}=$ Squared $\mathrm{X} 2$

The formula to determine t-table with significance $5 \%$ and $1 \%$ as follow:

$$
\begin{aligned}
& \text { Df }=\mathrm{N} 1+\mathrm{N} 2-2 \\
& =26+26-2 \\
& =50 \text { (see } t \text { table score) }
\end{aligned}
$$

Based on the statistical analysis there is 50 for the df value and the values of the $t_{\text {table }}$ 
significances based on the table are as follow:

a. At significance level 5\%: $\mathrm{t}_{\mathrm{t}}=2.00$

b. At significance level $1 \%: \mathrm{t}_{\mathrm{t}}=2.67$

$$
\begin{aligned}
t & =\frac{M 1-M 2}{\sqrt{\frac{\left(\sum X_{1}{ }^{2+} X_{2}{ }^{2}\right)\left(N 1+N_{2}\right)}{(N 1+N 2-2) N_{1} \cdot N_{2}}}} \\
& =\frac{79.04-65}{\sqrt{\frac{(1580.92+1858)(26+26)}{(26+26-2)}}} \\
& =\frac{14.04}{\sqrt{\left\{\frac{3438.92}{50}\right\}\left\{\frac{52}{676}\right\}}} \\
& =\frac{14.04}{\sqrt{\{68.78\}\{0.08\}}} \\
& =\frac{14.04}{\sqrt{5.50}} \\
& =\frac{14.04}{2.35} \\
& =\mathbf{5 . 9 7}
\end{aligned}
$$

According to the result of statistic analysis, it was obtained that the score of $\mathrm{t}_{\mathrm{o}}$ is $=5.97$ with the degree of freedom is (5)\%. The value of 50 is mentioned in the table about 2.00 (as the degree of significance). To prove the hypothesis, the data obtained from the experimental class is analyzed using the t-test formula. The research hypothesis is as follow:

a. If $t_{\text {observation }}>t_{\text {table, }}$ the alternative hypothesis is accepted. It means there is the effectiveness of using Mobile Assisted Language Learning (MALL) on students' pronunciation skills.

b. If $t_{\text {observation }}<t_{\text {table, }}$ the alternative hypothesis is rejected. It means there is no effect of using

Mobile Assisted Language Learning (MALL) on students' pronunciation skills.

According to the data, the value of observation is bigger than $t_{\text {table. }}$. The observation $=5.97>t_{\text {table }}=$ $2.00(5 \%)$ or observation $=5.97>t_{\text {table }}=2.67(1 \%)$. Since the value of observation is higher than the $\mathrm{t}_{\text {table }}$ then the alternative hypothesis is accepted. It means that there is an effect of using Mobile Assisted Language Learning (MALL) on students' pronunciation skills. It can also be seen that students who received teaching instruction with the MALL method get better scores than their peers who did not receive teaching instruction with the non-MALL method. It can be said that mobile application teaching instruction can be an alternative strategy in teaching pronunciation.

From the result above, it can be revealed that the use of Mobile Assisted Language Learning (MALL) can be used as an alternative strategy in teaching pronunciation to secondary school students. Results from pre-test and post-test scores in the experimental group showed significant improvement in students' performance. This result supports a previous study by AlKhayyat (2018) that states that teaching the English language as via MALL is an interesting experience for students, especially for English for Specific Purposes students. MALL can enhance students' speaking confidence, support students' ability to listen in a foreign language, and, most importantly, develop students' speaking performance. Meanwhile, the results also suggest that using MALL could improve students' skill in pronunciation. Through MALL, students have more opportunities to study and practice pronunciation of the words in English independently. MALL for pronunciation teaching application conveys useful and interesting features that could enhance students' motivation in learning. So, in the end, it could improve students' comprehension and skills.

These results were following the previous research done by Saran, M., Seferoglu, G., \& Cagiltay, K. (2009) which states that students who were sent multimedia messages studied supplementary materials more than students who studied the web- and paper-based materials and this many supplementary studies helped to the better pronunciation of words. Moreover, results 
obtained from the interview data indicated that students believed that using mobile phones for pronunciation learning is very effective.

The present study revealed that the students were more enthusiastic and were assisted by the presence of the mobile application as teaching instruction. The result supports the previous research done by Hadi \& Emzir (2016) that claims Mobil Assisted Language Learning (MALL) significantly helps the students in improving their ability to speak English.

\section{CONCLUSION}

The study revealed that the use of Mobile Assisted Language Learning (MALL) had a significant effect on improving students' pronunciation skills. The English teacher can use this application as one of the alternative strategies in the teaching of pronunciation. The findings showed that the mean scores of the experimental group in pre-test and post-test were 67.85 and 79.04. Meanwhile, the mean scores of the control group in pre-test and post-test were 61.65 and 65. Based on this data, students who were experiencing the Mobile-Assisted Language Learning (MALL) had better scores than their peers who have not. The finding also revealed that Mobile Assisted Language Learning (MALL) gives a positive influence on students' pronunciation skills, especially on the eighth-grade students of secondary school. In other words, the application of Mobile Assisted Language Learning (MALL) effectively improves students' pronunciation skills among secondary school students.

\section{REFERENCES}

Al-Khayyat, A. S. J. (2019). The Effect of Using Mobile-Assisted Language Learning (MALL) in Developing University Students' English Language Achievement. Journal of the College of Basic Education. https://www.researchgate.net/

Chinnery, G. M. (2006). Emerging Technologies Going to the MALL: Mobile-Assisted Language Learning. Language Learning \& Technology, 10(1), 9-16.

Educational Testing Service (1985). Educational Testing Service: Evaluation of Writing to Read. Princeton, NJ: Educational Testing Service.

Gholami, J., and Azami, G. (2012). An Introduction to Mobile Assisted Language Learning. International Journal of Management, It and Engineering (IJMIE), Vol II, No. 8.

Hadi, M. S., and Emzir, E. (2016). Improving English Speaking Ability through Mobile Assisted Language Learning (Mall) Learning Model. IJLECR - International Journal of Language Education and Culture Review, 2(2), 71 - 74. https://doi.org/10.21009/IJLECR.022.09.

Harunasari, S. Y., and Rahmat, A. (2015). Call-Based Instruction Model of Speaking English (A Developmental Research at the English Language Education Study Program of STKIP Kusuma Negara, Jakarta). IJLECR - International Journal of Language Education and Culture Review, 1(1), 65 - 78. https://doi.org/10.21009/IJLECR.011.07

Hewings, M. (2004). Pronunciation Practice Activities. Cambridge: Cambridge University Press.

Kim, H., and Kwon, Y. (2012). Exploring Smartphone Applications for Effective Mobile-Assisted Language Learning. Multimedia-Assisted Language Learning, 15(1), 31-57.

Kukulska-Hulme, A. and Shield, L. (2008). An overview of Mobile-Assisted Language Learning: From Content Delivery to Supported Collaboration and Interaction. ReCALL, 20(3), 271 -289.

Marks, J. (2007). English Pronunciation in Use Elementary: Self Study and Classroom Use. Cambridge: Cambridge University.

Pourhosein, G. A. (2016). What Factors Influence the English Pronunciation of EFL Learners? Modern Journal of Language Teaching Methods (MJLTM), 6(2), 314-326.

Richards, J. C., \& Richard, S. (2002). Longman Dictionary of Language Teaching and Applied Linguistics, $3^{\text {rd }}$ ed.UK: Pearson Education Limited. 
Saran, M., Seferoglu, G., and Cagiltay, K. (2009). Mobile Assisted Language Learning: English Pronunciation at Learners' Fingertips. Egitim Arastirmalari-Eurasian Journal of Educational Research, 34, 97-114.

Sudjiono, A. (2012). Pengantar Statistik Pendidikan. Jakarta: Rajawali Pers. 